\title{
PEMETAAN CAKUPAN IMUNISASI MR DAN KASUS CAMPAK RUBELLA DI PROVINSI BALI TAHUN 2019
}

\author{
Ni Made Suweni Handayani, Made Pasek Kardiwinata* \\ Program Studi Sarjana Kesehatan Masyarakat, Fakultas Kedokteran, Universitas Udayana \\ *Email : pkardiwinata@gmail.com
}

\begin{abstract}
ABSTRAK
Informasi mengenai cakupan imunisasi MR dan kasus campak rubella di Dinas Kesehatan pada umumnya disajikan dalam bentuk tabel dan grafik sehingga belum dapat digunakan untuk melihat detail informasi mengenai kedua hal tersebut secara geografis. Penelitian ini bertujuan untuk menggambarkan distribusi kejadian campak rubella dan cakupan imunisasi MR dalam bentuk kewilayahan di Provinsi Bali. Jenis penelitian yang digunakan adalah deskriptif. Analisis yang digunakan yaitu deskriptif dengan menyajikan peta. Hasil penelitian menunjukkan bahwa cakupan kampanye imunisasi MR di setiap desa di Provinsi Bali belum merata dan masih terdapat desa yang belum mencapai target 95\%. Masih ditemukan beberapa kasus pasca kampanye imunisasi MR di Provinsi Bali. Sebaran kasus suspek campak ditemukan paling banyak di daerah perkotaan dan padat penduduk seperti Kabupaten Badung, Klungkung, dan Kota Denpasar. Sedangkan kasus positif rubella ditemukan di daerah pedesaan terkait dengan status imunisasi yang belum lengkap. Dinas Kesehatan dapat memanfaatkan peta digital dalam pengambilan keputusan untuk mengendalikan campak dan rubella serta meningkatkan cakupan imunisasi MR dengan mempertimbangkan aspek kewilayahan, melakukan monitoring dan evaluasi terhadap suatu program pengendalian campak dan rubella yang telah dilaksanakan setiap tahunnya.
\end{abstract}

Kata Kunci: Pemetaan, Campak Rubella, Imunisasi

\begin{abstract}
The information about MR immunization coverage and measles rubella cases at the Health Department was generally presented in the form of tables and graphs so that it could not be used to see detailed information about measles rubella and MR immunization coverage geographically. This study aimed to describe the distribution of measles rubella and MR immunization coverage geographically in the province of Bali. This type of study is descriptive. The analysis used is descriptive with presenting the map. The results of the study showed that the coverage of the MR immunization campaign in each village in Bali was not evenly distributed and there were still villages that had not reached the target. Several cases are still found after the MR immunization campaign in Bali Province. Distribution of suspected cases of measles were the most found in urban and densely populated areas such as Badung, Klungkung, and Denpasar. While rubella positive cases found in rural areas related to incomplete immunization status. The Health Department can utilize digital maps in the process of decision making to control measles and rubella and increase MR immunization coverage by considering regional aspects, monitoring and evaluating a measles and rubella control program which has been done every year.
\end{abstract}

Keywords: Mapping, Measles Rubella, Immunization

\section{PENDAHULUAN}

Campak atau dikenal juga sebagai measles atau morbili adalah penyakit yang disebabkan oleh virus dan dapat ditularkan melalui batuk dan bersin. Gejala campak berupa demam tinggi, rash yang disertai batuk dan pilek serta konjungtivitis, namun sangat berbahaya apabila diseertai komplikasi pneumonia, meningitis, dan diare. Komplikasi penyakit campak menyebabkan lebih dari
562.000 anak per tahun meninggal di seluruh dunia pada tahun 2000. Rubella merupakan penyakit akut yang sering menginfeksi anak serta dewasa muda yang rentan. Penyebab rubella adalah togavirus jenis rubivirus. Virus ini dapat menular melalui sawar plasenta sehingga dapat menginfeksi janin.

Kasus campak yang dilaporkan melonjak pada tahun 2017 diakibatkan 
karena banyaknya negara yang mengalami wabah yang parah dan berkepanjangan. Terjadinya wabah campak di semua region WHO disebabkan karena adanya kesenjangan dalam cakupan imunisasi dan mengakibatkan 110.000 kematian terkait dengan penyakit ini (WHO, 2018). Insiden rate campak per 100.000 penduduk di Indonesia pada tahun 2011 hingga tahun 2017 mengalami penurunan dari 9,2 menjadi 5,6 per 100.000 penduduk, namun mengalami peningkatan sejak tahun 2015 hingga tahun 2017 yaitu dari 3,2 menjadi 5,6 per 100.000 penduduk akibat menurunnya cakupan campak sejak tahun 2012 sebesar 99,3\% menjadi 89,8\% pada tahun 2017. (Kemenkes RI, 2018b). Sejak tahun 2010 hingga 2015 diperkirakan terdapat 23.164 kasus campak dan 30.463 kasus rubella di Indonesia dan pada tahun 2015-2016 dilaporkan terdapat 226 kasus CRS. Kasus campak di Provinsi Bali pada tahun 2016 terlaporkan sebanyak 25 kasus dan meningkat pada tahun 2017 menjadi 179 kasus, selanjutnya mengalami penurunan pada tahun 2018 menjadi 17 kasus. Sedangkan rubella di Provinsi Bali dilaporkan sebanyak 148 kasus pada tahun 2017 dan meningkat menjadi 176 kasus pada tahun 2018.(Dinas Kesehatan Provinsi Bali,2019).

Sejak tahun 2000 lebih dari satu miliar anak di negara-negara dengan risiko tinggi telah mendapatkan imunisasi campak, sehingga pada tahun 2013 kematian akibat campak secara global telah mengalami penurunan sebesar $75 \%$. Program imunisasi adalah salah satu upaya pelayanan kesehatan untuk menurunkan angka kecacatan, kesakitan, dan kematian dari penyakit khususnya balita (Ponidjan, 2012). Imunisasi adalah salah satu cara untuk mencegah penyakit menular khususnya Penyakit yang Dapat Dicegah Dengan Imunisasi (PD3I) yang diberikan kepada anak sejak masih bayi hingga remaja dan dewasa.

Cakupan imunisasi campak secara global menurut (WHO, 2019) pada akhir tahun 2018, 86\% anak-anak telah mendapatkan satu dosis vaksin campak pada usia dua tahun, dan 171 negara telah memasukkan dosis kedua sebagai bagian dari imunisasi rutin serta $69 \%$ anak-anak menerima dua dosis vaksin campak sesuai dengan jadwal imunisasi nasional.

Pengendalian campak di Indonesia dimulai pada tahun 1982. Cakupan imunisasi campak semakin meningkat dan mencapai lebih dari 90\% pada tahun 1990 . Cakupan imunisasi campak di Indonesia menunjukkan peningkatan sejak tahun 2008 hingga tahun 2012. Namun kecenderungan penurunan terjadi sejak tahun 2012 sebesar 99,3\% menjadi 89,8\% pada tahun 2017.

Kegiatan kampanye MR adalah kesempatan yang penting untuk menutupi kesenjangan tersebut sehingga tidak terdapat daerah yang akan menjadi sumber penularan. Dengan cakupan yang tinggi dan merata minimal 95\% akan terbentuk herd immunity dan memutus rantai penularan campak dan rubella. (Kemenkes RI, 2017). Cakupan imunisasi campak di Provinsi Bali pada tahun 2017 mencapai 95\%. Kemudian pada tahun 2018 dilakukan kampenye imunisasi MR (Measles Rubella) dengan cakupan 98\%. Meskipun cakupan imunisasi cukup tinggi, namun KLB campak masih 
mungkin terjadi apabila masih adanya daerah dengan cakupan imunisasi yang rendah

Cakupan imunisasi dapat dilihat secara kewilayahan untuk tujuan intervensi dan pembuatan kebijakan terkait imunisasi. Sehingga penggunaan SIG bisa bermanfaat untuk hal tersebut yang karena sampai saat ini masih menggunakan tabel dan grafik dalam pengajian data cakupan imunisasi. Melalui sistem informasi geografis, informasi terkait cakupan imunisasi MR dan kasus campak rubella yang ada diintegrasikan dalam suatu peta untuk dapat mengetahui distribusi kasus campak rubella dan cakupan imunisasi MR di tiap desa/kelurahan dan mengetahui pola persebaran penyakit serta sebaran cakupan imunisasi MR apakah sudah merata atau belum.

Penyajian cakupan kampanye imunisasi MR dan kasus campak rubella dengan peta dapat memberikan informasi yang lebih baik pada dua variabel tersebut karena baik cakupan imunisasi maupun kejadian campak rubella berkaitan dengan karakteristik kewilayahan, yang sampai saat ini masih disajikan dengan tabel dan grafik sehingga belum bisa menggambarkan hal tersebut secara kewilayahan. Kasus campak dan rubella berkaitan dengan karakteristik kewilayahan seperti kepadatan penduduk, sosial ekonomi, dan wilayah rural urban. Kepadatan penduduk dapat menjadi persemaian subur bagi virus karena pemukiman yang padat dapat mempermudah penularan penyakit yang menular melalui udara, terutama penyakit campak yang penularannya melalui percikan ludah atau berupa cairan saat bersin. Selain itu, orang dengan sosial ekonomi yang rendah kemungkinan untuk berperilaku kurang sehat yang dapat meningkatkan risiko terkena suatu penyakit. Menurut (Som, S., 2010) sosial ekonomi memiliki pengaruh yang signifikan karena orang dengan sosial ekonomi yang baik memiliki kemungkinan menerima imunisasi penuh 1,8 kali lebih besar dibandingkan dengan orang dengan sosial ekonomi buruk. Campak dapat terjadi dimana saja dan endemis di masyarakat perkotaan serta dapat mencapai proporsi untuk terjadi epidemi setiap 2 - 4 tahun apabila terdapat $30-40 \%$ anak yang rentan karena belum mendapat vaksinasi. (Heniwati, 2015).

Menggunakan

pendekatan kewilayahan akan lebih memudahkan untuk menentukan daerah yang menjadi prioritas dengan membandingkan besar masalah antara satu wilayah dengan wilayah lainnya, sehingga dapat mengetahui lokasi yang rawan terhadap penularan campak. Selanjutnya pemerintah dapat fokus terhadap program yang disusun di wilayah tersebut. Oleh karena itu, peneliti tertarik dalam mengaplikasikan SIG untuk memetakan cakupan imunisasi MR, kasus campak rubella, dan informasi terkait.

\section{METODE PENELITIAN}

Penelitian ini menggunakan rancangan deskriptif untuk menggambarkan distribusi kasus campak dan rubella serta cakupan imunisasi MR per desa. Penelitian ini dilakukan selama 
empat bulan di Provinsi Bali dari bulan Maret sampai Juni 2020. Unit analisis dalam penelitian ini adalah unit administrasi desa. Data yang dikumpulkan dalam penelitian ini berupa data primer (titik koordinat suspek campak, kasus campak dan rubella) dan data sekunder (data persentase cakupan imunisasi MR Tahun 2018, data jumlah penduduk miskin di masing-masing Kabupaten/Kota Tahun 2016, data kepadatan penduduk Tahun 2018, dan data wilayah rural dan urban Tahun 2018). Pengolahan data dilakukan menggunakan aplikasi pengolahan peta. Analisis data dilakukan secara deskriptif dengan menyajikan peta.

\section{HASIL DAN DISKUSI}

\section{Distribusi Cakupan Imunisasi MR dan}

\section{Kasus Campak Rubella di Provinsi Bali}

Berdasarkan data sekunder yang didapatkan dari Dinas Kesehatan Provinsi Bali diketahui bahwa cakupan kampanye imunisasi MR dan sebaran kasus campak dan rubella yang ada di Provinsi Bali memiliki besaran yang bervariasi.

Gambar 1. Peta Distribusi Kasus Campak dan Rubella Tahun 2019 Setelah Dilakukan Kampanye Imunisasi MR Tahun 2018 per Kecamatan di Provinsi Bali

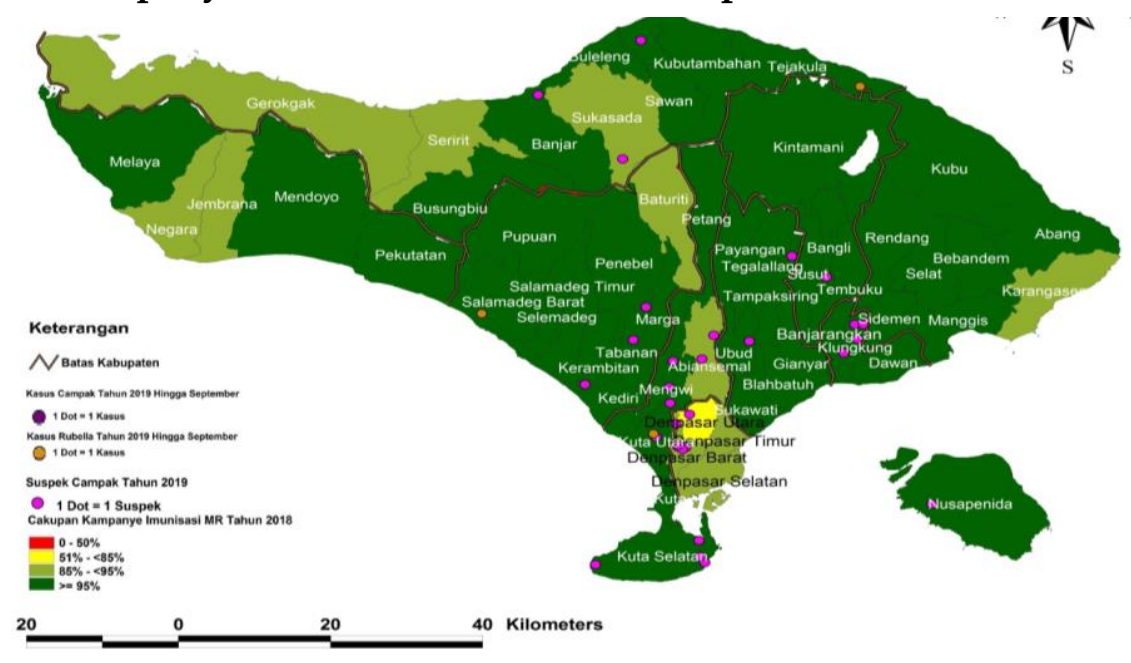

Kementrian Kesehatan RI menyatakan salah satu pencegahan penyakit campak dan rubella yang paling efektif adalah melalui program imunisasi MR. Efikasi dari vaksin campak hanya $85 \%$ sedangkan pemberian satu dosis vaksin kombinasi antara campak dan rubella (MR) akan memberikan efikasi hingga sebesar 98\%. Imunisasi MR harus mencapai cakupan minimal 95\% dan merata agar terbentuk herd immunity. (Kemenkes RI, 2017).

Menurut (Salim, Agus., Hari Basuki N., 2007) cakupan imunisasi memiliki hubungan yang signifikan terhadap kejadian campak. Berdasarkan penelitian tersebut dipercaya cakupan imunisasi dapat menjadi indikator untuk memprediksi KLB campak. Data cakupan imunisasi dapat menggambarkan status wilayah tersebut beresiko KLB atau tidak. Berikut merupakan peta distribusi Kasus Campak dan Rubella Tahun 2019 Setelah Dilakukan Kampanye Imunisasi MR Tahun 2018 per Kecamatan di Provinsi Bali: 
Berdasarkan gambar 1 secara administrasi kecamatan, hampir setiap kecamatan sudah mencapai target kampanye imunisasi MR yaitu 95\%, hanya sedikit kecamatan dengan cakupan imunisasi dibawah 95\% yaitu Kecamatan Gerokgak, Seririt, dan Sukasada di Kabupaten Buleleng, Kabupaten Jembrana bagian Barat (Kecamatan Negara, Kecamatan Jembrana), Kabupaten Tabanan bagian Utara (Kecamatan Baturiti), Kabupaten Badung bagian Timur (Kecamatan Abiansemal), Kabupaten Karangasem bagian Timur (Kecamatan Karangasem), dan seluruh kecamatan di Kota Denpasar khususnya Kecamatan Denpasar Utara dengan cakupan imunisasi dibawah $85 \%$.

Pada peta juga menunjukkan bahwa secara kewilayahan cakupan kampanye imunisasi MR yang belum mencapai target cenderung mengelompok, sebagian besar desa/kelurahan dengan cakupan kampanye imunisasi MR $<95 \%$ bersebelahan dengan desa/kelurahan lainnya yang memiliki cakupan <95\% pula. Perbedaan cakupan imunisasi di tiap daerah kemungkinan disebabkan oleh berbagai hal seperti perbedaan sosial budaya di daerah dengan banyak penduduk muslim sehingga menyebabkan adanya penolakan terhadap imunisasi MR. Dalam beberapa penelitian menunjukkan masih adanya penolakan terhadap imunisasi MR seperti penelitian oleh (Swandari \& Kardiwinata, 2019) yaitu hanya 77,63\% ibu - ibu di Kampung Jawa Wanasari Kota Denpasar yang menerima pemberian imunisasi MR pada balitanya. Perbedaan kondisi sosial ekonomi juga berpengaruh terhadap kesadaran warga untuk belajar dalam menerima program imunisasi. (Rusmana, 2013).

Virus campak dan rubella dapat ditularkan melalui droplet yang keluar dari hidung, mulut, atau tenggorokan orang yang terinfeksi virus pada saat batuk, bicara, bersin, atau melalui sekresi hidung. Oleh karena itu, penularan penyakit campak dan rubella sangat mudah terjadi. Dalam memahami distribusi spasial kasus campak dan rubella dan pola penularannya sangat penting sangat penting untuk memperkirakan munculnya kasus baru dan penyebarannya ke wilayah geografis yang baru dengan demikian akan membantu memberikan informasi mengenai target yang akan diberikan intervensi. Seperti yang terlihat pada gambar 2, suspek campak terjadi pada desa/kelurahan dengan jarak yang berdekatan di beberapa kabupaten/kota di Provinsi Bali yaitu Kabupaten Klungkung, Kabupaten Badung, dan Kota Denpasar.

Pelaksanaan surveilans yang intensif akan bermanfaat untuk memahami pola transmisi kasus dan pelaksanaan kampanye imunisasi MR tepat untuk memutus transmisi. Sejak tahun 2011, surveilans campak dilakukan dengan pendekatan berbasis individu (CBMS). Surveilans campak yang sensitif sangat penting untuk memonitor kemajuan program eliminasi campak. Salah satu strateginya adalah dengan meningkatkan sensitifitas penemuan kasus, yaitu mengubah definisi operasional suspek campak menjadi demam dan ruam makulopapular. 
Adapun pelaksanaan penemuan kasus campak dan rubella di Provinsi Bali dari tingkat puskesmas, fasilitas kesehatan swasta, rumah sakit, dan kabupaten/kota adalah sebagai berikut:

1. Pada tingkat puskesmas, penemuan kasus bersumber dari laporan puskesmas dan fasyankes swasta yang potensial. Puskesmas melibatkan peran aktif kader untuk melaporkan ke petugas puskesmas setiap adanya kasus dengan gejala yang mengarah ke suspek campak. Petugas puskesmas wajib untuk melakukan penyelidikan epidemiologi dengan menggunakan form investigasi kasus suspek campak (form MR-01) untuk setiap suspek yang dilaporkan ke puskesmas, laporan dari rumah sakit, dan dari fasyankes lainnya. Pada saat melakukan penyelidikan epidemiologi, petugas puskesmas mencari kasus tambahan lainnya dengan menanyakan pada keluarga penderita apakah terdapat kasus yang sama di keluarga maupun di tempat lain.

2. Pada tingkat fasilitas kesehatan swasta, setiap praktik dokter, bidan, perawat dan fasilitas pelayanan kesehatan swasta melaporkan setiap kasus suspek campak yang ditemukan ke puskesmas wilayah kerja fasyankes tersebut menggunakan form notifikasi untuk kasus suspek PD3I (form MR-03) melalui SMS, WhatsApp, atau E-Mail untuk kemudian dilakukan penyelidikan epidemiologi oleh puskesmas.
3. Pada tingkat rumah sakit, tim surveilans rumah sakit bertanggung jawab terhadap penemuan dan pelaporan kasus. Setiap kasus suspek campak yang ditemukan di semua unit yang berpotensi seperti instalasi rawat jalan dan rawat inap, instalasi gawat darurat, instalasi rekam medis, dan NICU/PICU/ICU. Kontak person di setiap bangsal, poliklinik dan rekam medis menelusuri setiap kasus maupun kematian yang disebabkan oleh diare, bronchopneumonia, ensefalitis apakah merupakan komplikasi dari penyakit campak. Apabila merupakan komplikasi dari penyakit campak maka kasus tersebut dicatat dan dilaporkan sebagai kasus campak.

4. Pada tingkat kabupaten/kota, petugas dinas kesehatan kabupaten/kota setiap minggu akan mengunjungi rumah sakit di wilayah kerjanya untuk mereview register, verifikasi, dan validasi data rekam medik. Setiap kasus campak yang ditemukan dan dilaporkan dari rumah sakit maka akan segera diinformasikan ke puskesmas untuk dilakukan penyelidikan epidemiologi. Setiap sinyal/alert yang muncul pada SKDR, akan dilakukan verifikasi oleh dinas kesehatan kabupaten/kota ke puskesmas setiap hari senin, apabila data valid maka dilakukan investigasi di lapangan.

Sebelum dilakukannya imunisasi MR, berdasarkan data Cased Based Measles Surveillance Provinsi Bali Tahun 2017 
dilaporkan bahwa jumlah suspek yang dilakukan pengambilan spesimen untuk pemeriksaan laboratorium sebanyak 564 orang dengan hasil pemeriksaan laboratorium IgM Campak (+) sebanyak 179 orang, IgM Rubella (+) 148 orang, dan sebanyak 237 orang menunjukkan hasil (-) baik untuk campak maupun rubella. Kemudian pada tahun 2018, dilaporkan jumlah suspek yang dilakukan pemeriksaan laboratorium sebanyak 270 orang, dengan hasil pemeriksaan laboratorium IgM Campak (+) sebanyak 17 orang, IgM Rubella (+) 176 orang, dan sebanyak 77 orang menunjukkan hasil (-). Pada Bulan Agustus hingga Desember Tahun 2018 dilakukan kampanye imunisasi MR sehingga pada tahun 2019

jumlah suspek yang dilakukan pemeriksaan laboratorium sebanyak 28 orang dengan tidak ditemukannya IgM Campak (+), IgM Rubella (+) 3 orang, dan sebanyak 25 orang menunjukkan hasil (-)..

Berikut merupakan peta distribusi kasus campak dan rubella tahun 2019 berdasarkan status imunisasi atau dosis vaksinasi yang diterima suspek campak sebelum sakit dan cakupan kampanye imunisasi MR tahun 2018 per desa di Provinsi Bali:

Gambar 2. Peta Distribusi Kasus Campak dan Rubella Tahun 2019 Berdasarkan Status Imunisasi dan Cakupan Kampanye Imunisasi MR Tahun 2018 per Desa di Provinsi Bali

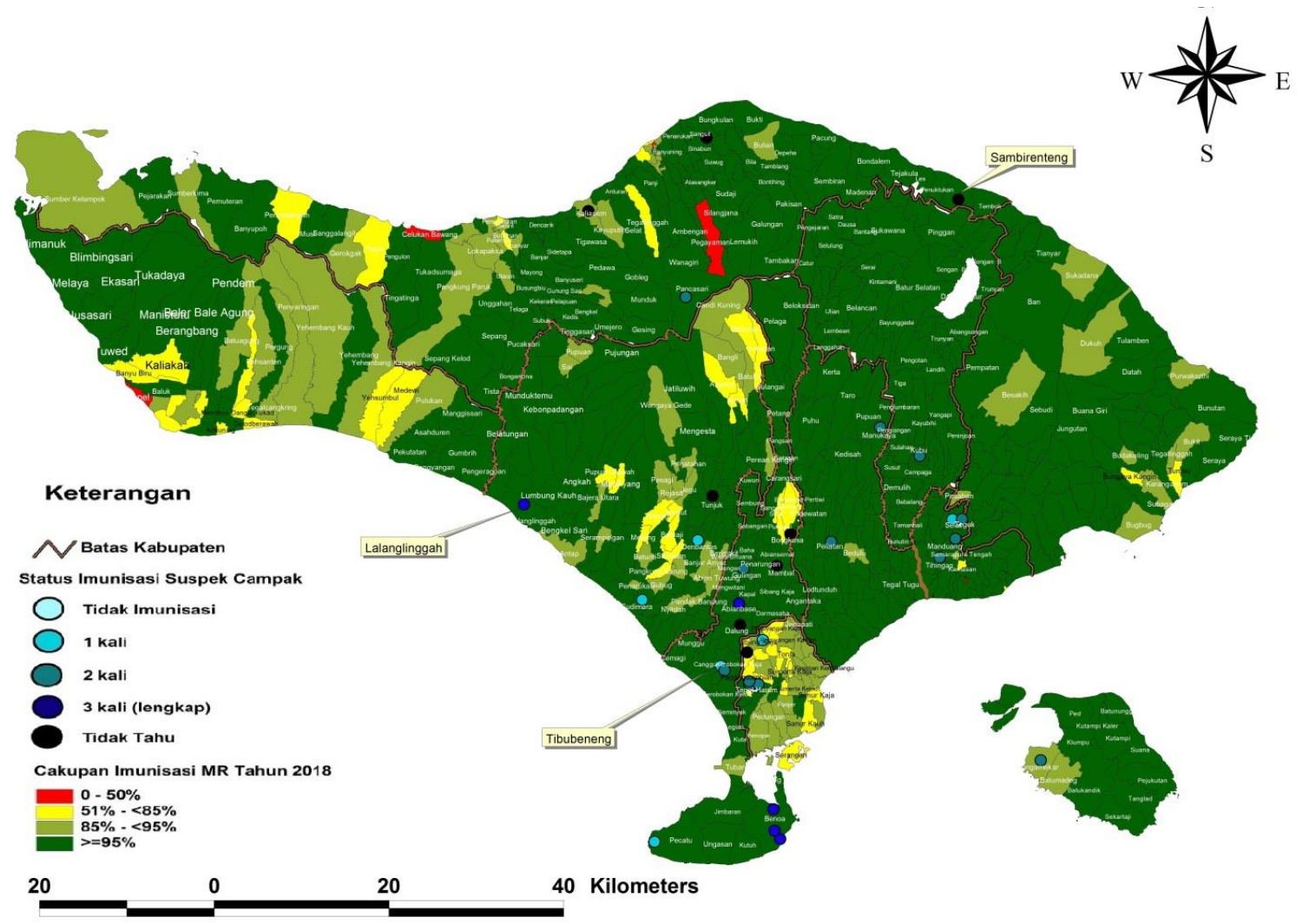


Berdasarkan hasil penelitian pada gambar 2 bahwa sebagian besar daerah di Provinsi Bali sudah memiliki cakupan imunisasi MR 95\% bahkan ada yang melebihi dari target tersebut. Namun di daerah tersebut masih ditemukan adanya suspek campak bahkan positif rubella sebanyak 3 kasus yaitu di Desa Lalang Linggah, Tibubeneng, dan Sambirenteng dengan masing-masing sebanyak 1 kasus. Meskipun cakupan imunisasi sudah tinggi, namun kasus campak dan rubella masih dapat terjadi karena status imunisasi yang belum lengkap atau tidak imunisasi sama sekali seperti pada gambar 2 yang menunjukkan status imunisasi atau dosis imunisasi yang diterima oleh suspek campak. Sebagian besar suspek campak memiliki status imunisasi yang tidak lengkap yaitu hanya 1 atau 2 kali atau bahkan tidak imunisasi sama sekali. Sejalan dengan penelitian oleh (Giarsawan, Asmara, \& Yulianti, 2012) yaitu anak dengan status imunisasi yang tidak lengkap memiliki kemungkinan 16,923 kali lebih beresiko untuk terkena campak dan campak. Menurut (Kemenkes RI, 2018a) anak harus mendapatkan minimal 2 dosis imunisasi yang diberikan pada usia 9 bulan dan 18 bulan untuk mendapatkan kekebalan secara optimal terhadap penyakit campak dan rubella. Selanjutnya untuk memastikan setiap anak sudah mendapatkan perlindungan terhadap penyakit campak dan rubella, maka diberikan 1 dosis lagi pada saat menginjak kelas 1 sekolah dasar. Namun, suspek campak dan positif rubella juga terjadi pada status imunisasi yang sudah lengkap, dikhawatirkan antibodi tidak terbentuk meskipun sudah mendapatkan imunisasi.

Suspek campak maupun kasus campak rubella tidak terdapat di Kabupaten Jembrana yang memiliki cukup banyak desa/kelurahan yang tidak mencapai target cakupan kampanye imunisasi MR. Hal ini bisa saja disebabkan oleh surveilans campak dan rubella yang kurang baik. Seperti pada penelitian oleh (Anggaraini, Umbul, \& W.K, 2016) yang menunjukkan kekurangan pelaksanaan sistem surveilans di tingkat puskesmas menyebabkan kualitas, sensitivitas, dan stabilitas data rendah.

Selain itu, suspek campak masih banyak terdapat di daerah dengan cakupan tinggi kemungkinan disebabkan oleh ketidaktepatan dalam membuat perkiraan target imunisasi mengingat terjadinya mobilitas penduduk seperti di Kabupaten Badung, Tabanan, Jembrana, Gianyar, dan Kota Denpasar yang memiliki angka mobilitas yang tinggi ditandai dengan banyaknya jumlah penduduk migran. Penyebab lainnya yaitu tidak meratanya cakupan imunisasi, seperti masih terdapat desa/kelurahan yang tidak mencapai target bahkan memiliki cakupan imunisasi yang sangat rendah yaitu di bawah 50\%. Selain itu, dapat juga disebabkan karena adanya kesalahan dalam penanganan vaksin di lapangan seperti cold chain vaksin yang menyebabkan tidak terbentuknya kekebalan. (Arianto, Setiawati, Adi, Hadisaputro, \& Budhi, 2018). Meskipun demikian, apabila terdapat kasus campak dan rubella maka ditangani sesuai dengan prosedur penanganan, namun penularan sulit terjadi karena cakupan imunisasi 
sudah tinggi dan membentuk herd immunity.

Berbagai macam penyakit sering dikaitkan dengan tingkat sosial ekonomi suatu masyarakat. Tingkat sosial ekonomi seseorang dapat dilihat melalui tingkat kemiskinan seseorang Hubungan sosial ekonomi dengan hal kesehatan dapat menjadi alasan bahwa sosial ekonomi merupakan salah satu faktor yang berpengaruh terhadap kejadian penyakit yaitu salah satunya campak. Sejalan dengan penelitian oleh (Som, S., 2010) yaitu sosial ekonomi memiliki pengaruh yang signifikan karena orang dengan sosial ekonomi yang baik memiliki kemungkinan menerima imunisasi penuh 1,8 kali lebih besar dibandingkan dengan orang dengan sosial ekonomi buruk. Keadaan sosial seseorang dapat menentukan akses seseorang terhadap kesehatannya. Dengan pendapatan yang tinggi maka kemungkinan untuk memperoleh sarana akan lebih baik diantaranya sumber informasi dengan tujuan untuk menambah ilmu pengetahuan pada masyarakat.

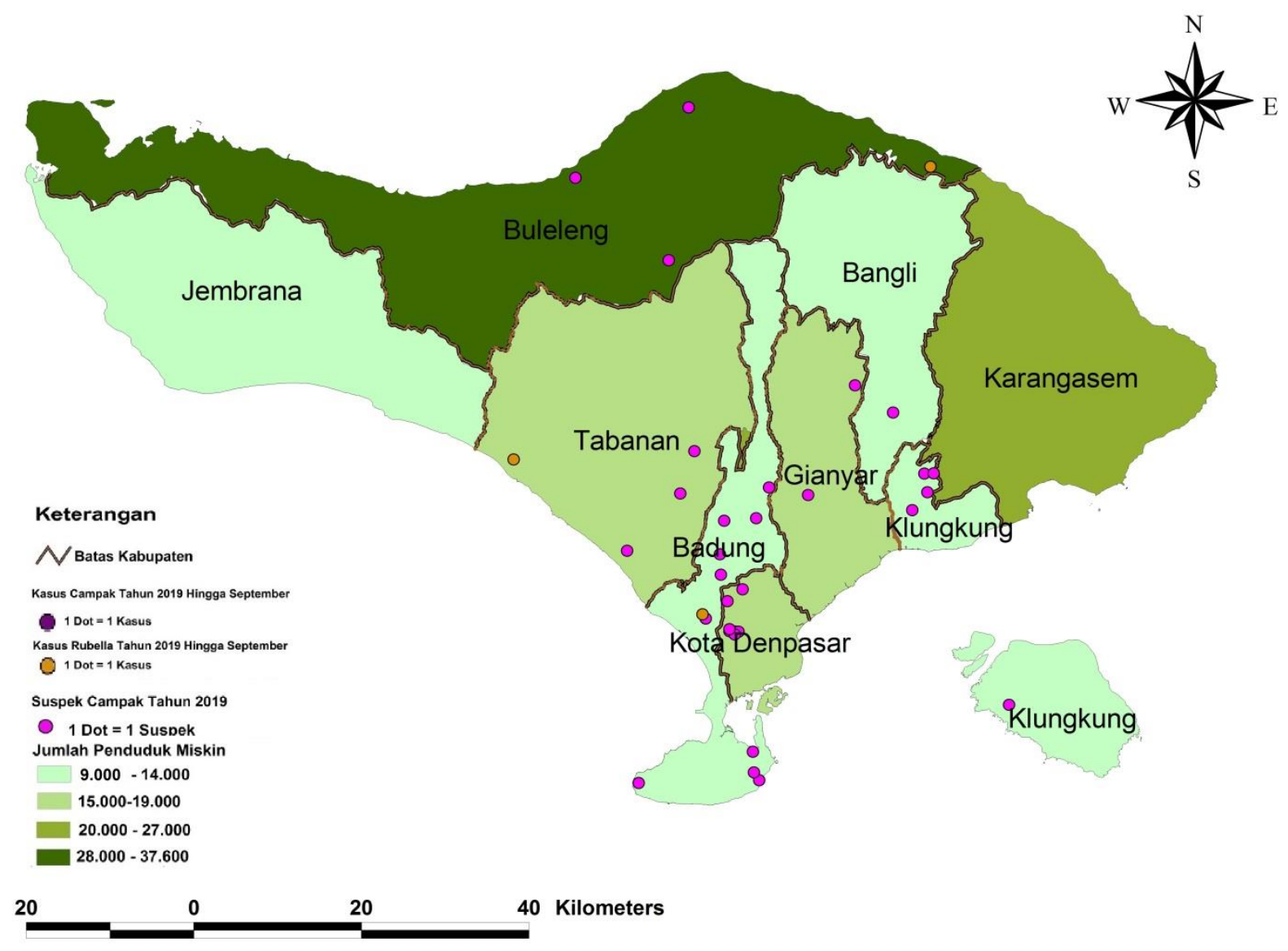

Gambar 3. Peta Distribusi Kasus Campak dan Rubella Tahun 2019 serta Jumlah Penduduk Miskin di Provinsi Bali 
Berdasarkan gambar 3 diketahui bahwa sebagian besar wilayah dengan jumlah penduduk miskin yang tinggi terdapat suspek campak. Penelitian (Yanitasari, 2011) yang menunjukkan bahwa terdapat hubungan status ekonomi responden dengan kejadian campak yaitu responden dengan status ekonomi rendah memiliki peluang anak terkena campak sebesar 14 kali. Rendahnya status ekonomi dapat mempengaruhi daya beli terhadap makanan dengan nilai gizi yang baik sehingga pemenuhan gizi balita rendah dan berdampak pada menurunnya daya tahan tubuh anak sehingga mudah untuk terinfeksi virus campak. Namun jumlah suspek campak terbanyak berada di Kabupaten Badung yang memiliki jumlah penduduk miskin yang rendah dibandingkan dengan Kabupaten Buleleng yang memiliki jumlah penduduk miskin tertinggi. Selain itu, wilayah dengan jumlah penduduk miskin yang rendah seperti Kabupaten Bangli dan Klungkung juga terdapat lebih banyak suspek campak dibandingkan Kabupaten Karangasem dengan jumlah penduduk miskin yang lebih tinggi. Hal ini kemungkinan terjadi karena meskipun status ekonomi yang tinggi apabila tidak disertai dengan tingkat pemahaman yang baik terhadap penyakit campak dan rubella maka risiko untuk terpapar penyakit tersebut akan sama besarnya. (Batubara \& Oktaviani, 2018). Selain itu, pendapatan yang tinggi namun masih terkena campak dapat disebabkan karena faktor ibu yang masih mengabaikan imunisasi campak pada anak dan pendapatan yang ada dialokasikan keada keperluan lain seperti keperluan sekolah dan biaya hidup (Marniasih, Hermawan, \& Abidin, 2012). Dapat juga disebabkan karena sistem surveilans yang kurang baik sehingga penemuan terhadap kasus campak juga kurang.

Kepadatan penduduk dapat menjadi persemaian subur bagi virus karena pemukiman yang padat dapat mempermudah penularan penyakit yang menular seperti campak dan rubella yang penularannya melalui percikan ludah atau berupa cairan saat bersin.

Secara teori, semakin padat penduduk di suatu wilayah maka penularan penyakit infeksi dari satu orang ke orang lainnya juga semakin mudah. Sejalan dengan penelitian oleh (Ayu, Nugroho, \& Kusnanto, 2016) yang membuktikan secara spasial bahwa terdapat korelasi antara kepadatan penduduk dengan kejadian campak. Penyakit campak dan rubella memiliki kemampuan untuk menular yang sangat tinggi. Distribusi kasus campak dan rubella serta kepadatan penduduk di Provinsi Bali dapat dilihat pada peta berikut: 


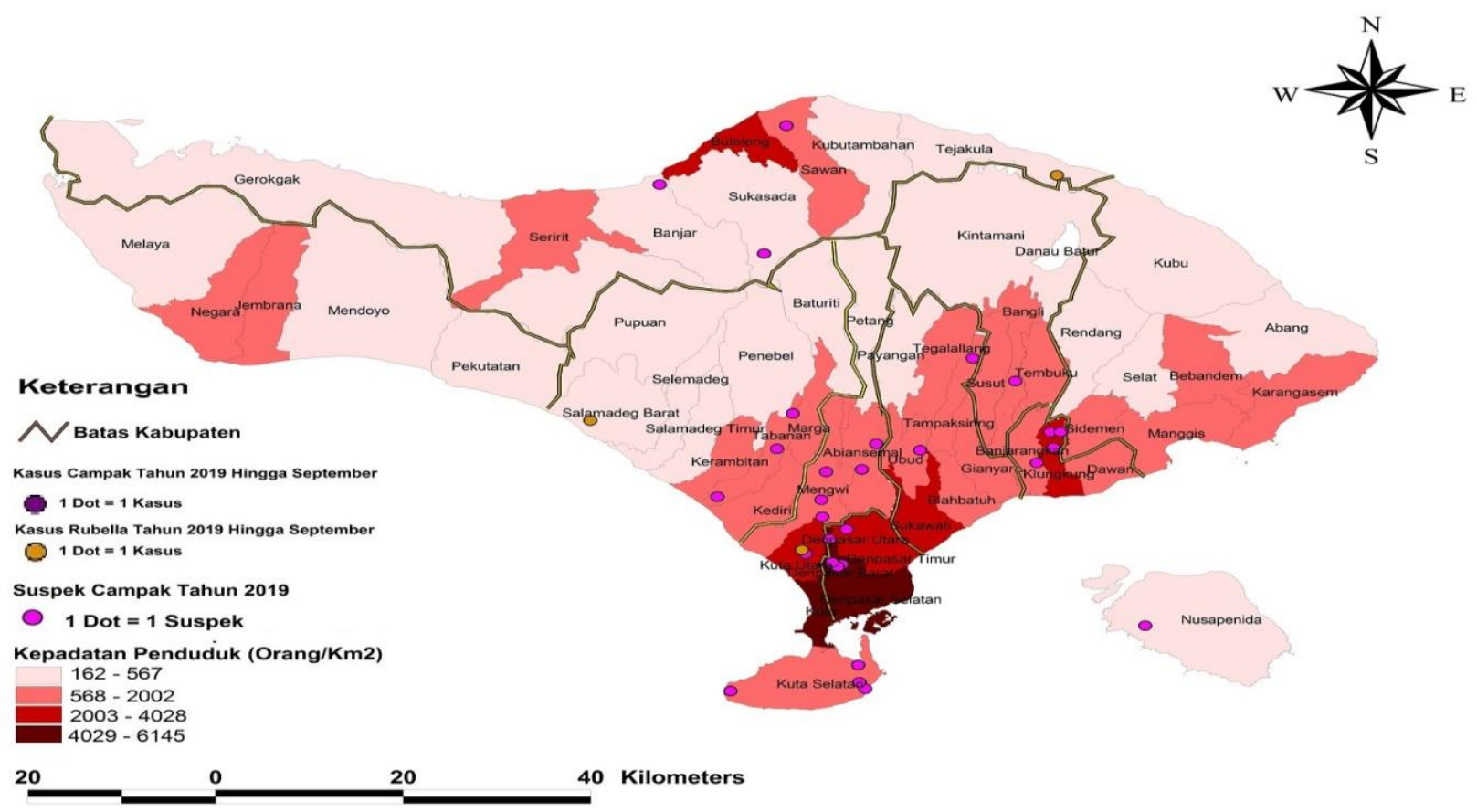

Gambar 4. Peta Distribusi Kasus Campak dan Rubella Tahun 2019 serta Kepadatan Penduduk

Gambar 4 menunjukkan sebaran suspek campak di Provinsi Bali cenderung mengikuti sebaran kepadatan penduduk. Suspek campak lebih banyak terjadi pada kecamatan dengan kepadatan penduduk sedang (Sawan, Abiansemal, Mengwi, Ubud, Susut, Kuta Selatan) dan tinggi (Klungkung, Denpasar Barat, Kuta Utara). Hal ini dikarenakan sebuah wilayah kota yang padat penduduk dapat dijadikan proses perkembangbiakan virus. Virus akan berkembang biak dengan leluasa, berpindah dari satu orang ke orang lain yang tidak memiliki kekebalan tubuh. Tingginya tingkat kepadatan penduduk disebabkan karena adanya migrasi penduduk dari daerah pedesaan ke daerah perkotaan. Penduduk dan lingkungannya memiliki hubungan yang saling berinteraksi secara terus menerus sehingga memungkinkan untuk timbulnya suatu penyakit. Pemukiman yang padat dapat mempermudah penularan. Kepadatan penduduk sangat berhubungan dengan herd immunity untuk mempengaruhi terjadinya penularan virus.(Heniwati, 2015). Pada peta menunjukkan, daerah dengan kepadatan penduduk sedang juga terdapat banyak suspek campak, hal ini bisa saja disebabkan karena daerah tersebut memiliki jumlah balita yang lebih banyak, sehingga lebih banyak terdapat suspek campak yang umumnya menyerang anak-anak yang berusia $<5$ tahun. Seperti pada penelitian (Nurani, 2012) yang menunjukkan insiden campak tertinggi paling banyak terjadi pada usia di bawah 5 tahun setiap tahunnya.

Distribusi kasus campak dan rubella serta wilayah rural urban dapat 
divisualisasikan dari segi geografis kumuh dan miskin, serta daerah yang yaitu sebagai berikut: $\quad$ populasinya padat. (Nurani, 2012). Selain

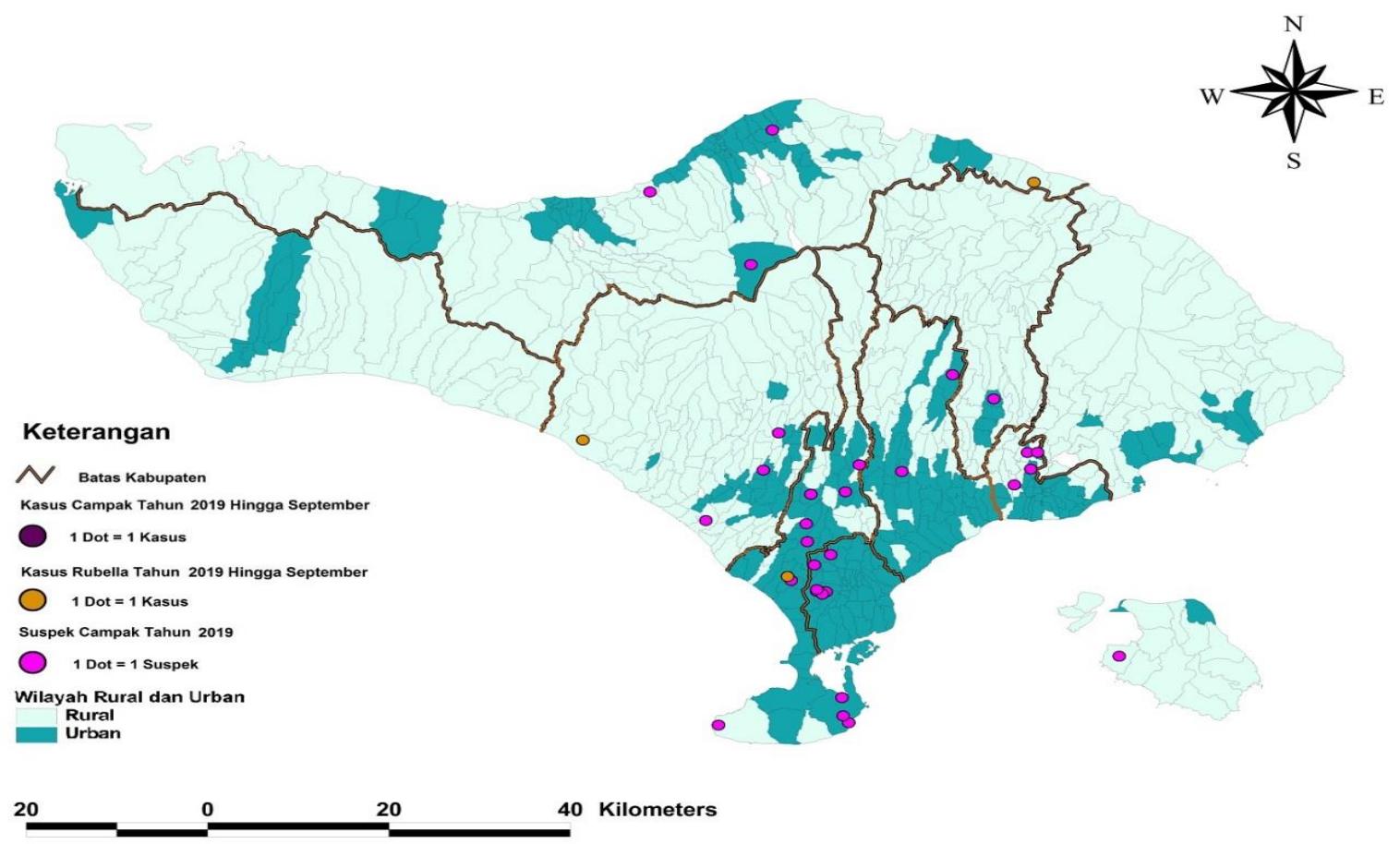

Gambar 5. Peta Distribusi Kasus Campak dan Rubella Tahun 2019 serta Wilayah Rural Urban

$\begin{array}{cll}\text { Wilayah } & \text { perkotaan } & \text { (urban) dan } \\ \text { pedesaan } & \text { (rural) } & \text { berpengaruh }\end{array}$ berpengaruh terhadap kejadian campak dan rubella. Menurut penelitian oleh (Heniwati, 2015) campak endemis di masyarakat metropolitan dan dapat mencapai proporsi untuk terjadi KLB setiap 2-4 tahun. Hal ini disebabkan daerah perkotaan memiliki jumlah penduduk yang lebih padat dibandingkan dengan daerah pedesaan.

Sejalan dengan hasil penelitian pada gambar 5 yaitu suspek campak lebih banyak terdapat di wilayah perkotaan dibandingkan wilayah pedesaan. Diketahui bahwa penularan penyakit campak lebih mudah terjadi pada perumahan yang padat, daerah yang itu, suspek campak yang ditemukan lebih banyak di perkotaan bisa juga disebabkan karena surveilans di perkotaan lebih baik, sehingga penemuan kasus menjadi tinggi.

\section{SIMPULAN}

1. Cakupan kampanye imunisasi MR di setiap daerah di Provinsi Bali sebagian besar sudah mencapai target $95 \%$ bahkan melebihi dari target tersebut namun cakupan kampanye imunisasi MR belum merata karena masih terdapat daerah yang belum mencapai target yaitu Kecamatan Gerokgak, Seririt, dan Sukasada di Kabupaten Buleleng, Kabupaten Jembrana bagian Barat (Kecamatan Negara, 
Kecamatan Jembrana), Kabupaten Tabanan bagian Utara (Kecamatan Baturiti), Kabupaten Badung bagian Timur (Kecamatan Abiansemal), Kabupaten Karangasem bagian Timur (Kecamatan Karangasem), dan seluruh kecamatan di Kota Denpasar khususnya Kecamatan Denpasar Utara dengan cakupan imunisasi dibawah $85 \%$.

2. Suspek campak dan positif rubella lebih banyak ditemukan di daerah dengan cakupan tinggi terkait dengan riwayat status imunisasi yang belum lengkap dan surveilans campak yang kurang sensitif.

3. Sebaran suspek campak di Provinsi Bali cenderung mengikuti sebaran kepadatan penduduk dan mengelompok pada daerah perkotaan (urban) dan kepadatan penduduk tinggi.

\section{SARAN}

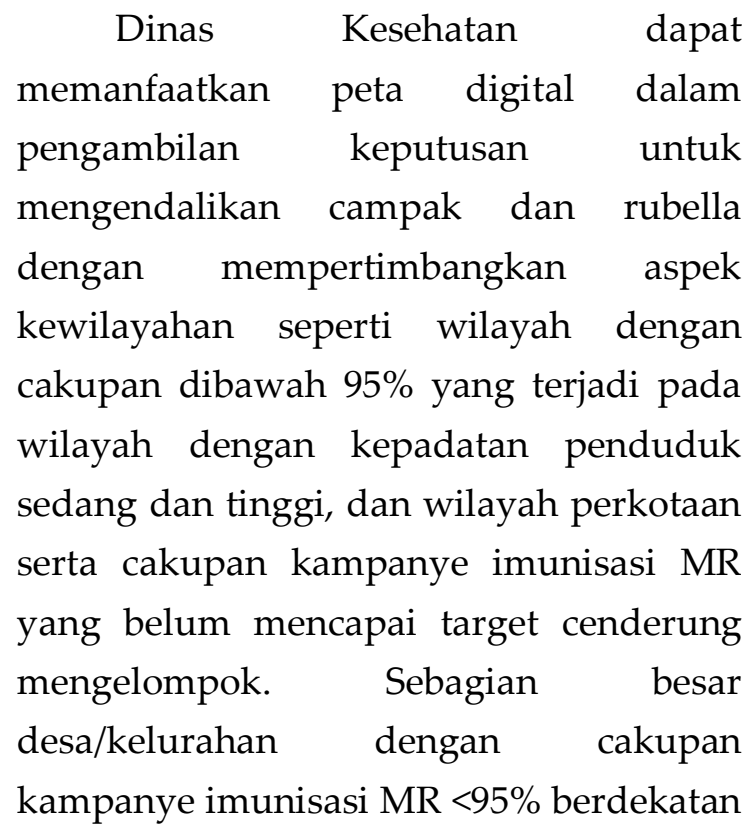

dengan desa/kelurahan lainnya yang memiliki cakupan $<95 \%$ pula. Demikian pula suspek campak yang terjadi pada desa/kelurahan dengan jarak yang berdekatan. Selain itu, Dinas Kesehatan juga dapat menggunakan peta digital untuk melakukan monitoring dan evaluasi terhadap suatu program pengendalian campak dan rubella yang telah dilaksanakan setiap tahunnya.

Puskesmas dan Rumah Sakit diharapkan meningkatkan penemuan kasus campak dan rubella melalui sistem surveilans yang lebih baik. Bagi peneliti selanjutnya, perlu adanya penelitian lebih lanjut untuk mengetahui faktor-faktor yang menyebabkan rendahnya cakupan imunisasi MR di daerah selain Denpasar dan penelitian sero survey terhadap IgM Campak dan IgM Rubella pada anak-anak yang sudah mendapatkan imunisasi MR untuk mengetahui apakah imunitas terhadap penyakit campak dan rubella sudah terbentuk.

\section{DAFTAR PUSTAKA}

Anggaraini, R. D., Umbul, C., \& W.K, B. (2016). Evaluasi Sistem Surveilans Campak Di Dinas Kesehatan Kabupaten Bangkalan. Jurnal Wiyata, 3(2), 174-186.

Arianto, M., Setiawati, M., Adi, M. S., Hadisaputro, S., \& Budhi, K. (2018). Beberapa Faktor Risiko Kejadian Campak Pada Balita di Kabupaten Sarolangun. Jurnal Epidemiologi Kesehatan Komunitas, 3(1), 41. https://doi.org/10.14710/jekk.v3i1.312 7

Ayu, R. D., Nugroho, A., \& Kusnanto, H. 
(2016). Spatial Analysis of Measles Risk Areas in Bantul District of Yogyakarta Province. Berita Kedokteran Masyarakat, 32(10), 393. https://doi.org/10.22146/bkm.11416

Batubara, A. R., \& Oktaviani, W. (2018). Faktor Risiko yang Memengaruhi Kejadian Campak di Wilayah Kerja Puskesmas Kuta Makmur Kabupaten Aceh Utara. Journal of Healthcare Technology and Medicine, 4(2), 225. https://doi.org/10.33143/jhtm.v4i2.212

Giarsawan, N., Asmara, I. W. S., \& Yulianti, A. E. (2012). Faktor-Faktor yang Mempengaruhi Kejadian Campak di Wilayah Puskesmas Tejakula I Kecamatan Tejakula Kabupaten Buleleng Tahun 2012. Jurnal Kesehatan Lingkungan, 4(2), $140-$ 145.

Heniwati, L. (2015). Analisis Spasiotemporal Kejadian Campak Di Provinsi Jawa Timur Tahun 2009-2013. Digital Repository Universitas Jember. https://doi.org/10.1242/jcs.150862

Kemenkes RI. (2017). Petunjuk Teknis Kampanye Imunisasi Measles Rubella (MR). Petunjuk Teknis Kampanye Imunisasi Measles Rubella (MR), 208. https://doi.org/10.1039/b612259k

Kemenkes RI. (2018a). Imunisasi MR Lindungi Anak Indonesia dari Kecacatan. Retrieved December 10, 2019, from https://www.depkes.go.id/article/prin t/18080200002/imunisasi-mrlindungi-anak-indonesia-darikecacatan.html
Kemenkes RI. (2018b). Situasi Campak dan Rubella di Indonesia, 6.

Marniasih, W., Hermawan, D., \& Abidin, Z. (2012). Faktor-faktor Yang Berhunungan Dengan Kejadian Campak Di Wilayah Kerja Puskesmas Natar Kabupaten Lampung Selatan Tahun 2012. Jurnal Dunia Kesmas, 1(April), 1-10.

Nurani, D. (2012). Gambaran Epidemiologi Kasus Campak Di Kota Cirebon Tahun 2004-2011 (Studi Kasus Data Surveilans Epidemiologi Campak Di Dinas Kesehatan Kota Cirebon). Jurnal Kesehatan Masyarakat Universitas Diponegoro, 1(2), 18799.

Ponidjan, T. S. (2012). Hubungan Tingkat Pendidikan Ibu Dengan Status Imunisasi Bayi Di Wilayah Kerja Puskesmas Bahu Kecamatan Malalayang. Poltekkes Kemenkes Manado, Volume $1 \mathrm{~N}$.

Rusmana, D. (2013). Beberapa Faktor yang Mempengaruhi Keberhasilan Program Imunisasi di Kecamatan Banjaran Kabupaten Bandung: Ditinjau dari Dimensi Pendidikan Luar Sekolah. Bandung: Universitas Pendidikan Indonesia. Sari.

Salim, Agus., Hari Basuki N., F. S. (2007). Indikator Prediksi Kejadian Luar Biasa (KLB) Campak di Provinsi Jawa Barat. The Indonesian Journal of Public Health, Vol 4 No 3, 112-116.

Som, S., et al. (2010). Sosioeconomic Impact on Child Immunisation in the Districts of West Bengal, India. Singapore Med J, 51(5), 406-412. 
Arc. Com. Health • April 2021

ISSN: 2527-3620

Swandari, N. L. P. I., \& Kardiwinata, M. P. (2019). PENERIMAAN IBU - IBU MUSLIM TERHADAP IMUNISASI MEASLES RUBELLA PADA BALITA DI KAMPUNG JAWA WANASARI, KOTA DENPASAR. Archive of Community Health, 6(2), 72-85.

WHO. (2018). Measles Cases Spike Globally Due to Gaps in Vaccination Coverage. Retrieved from https://www.who.int/newsroom/detail/29-11-2018-measlescases-spike-globally-due-to-gaps-invaccination-coverage

WHO. (2019). Immunization Coverage. Retrieved from https://www.who.int/newsroom/factsheets/detail/immunization-coverage Yanitasari, F. (2011). Faktor yang Berhubungan dengan Kejadian Campak di Wilayah Kerja Puskesmas Kemiling Bandar Lampung Tahun 2010. FKM Malahayati, Lampung. 